\title{
ATTITUDES OF SPOUSES TOWARD UNPAID WORK, AND POSSESSION OF ECONOMIC RESOURCES IN JORDANIAN FAMILY AND ITS RELATIONSHIP WITH THEIR SOCIAL STATUS
}

\author{
DINA NASER TAHAT \& Dr. MUHAMMAD FAYEZ AL-TARAWNEH \\ University of Jordan, Amman, Jordan
}

\begin{abstract}
This study aimed to identify the differences in the attitudes of husbands and wives towards unpaid work and the possession of economic resources and their relationship to the social status of women and men in the Jordanian society. The study sample consisted of (142) husbands and wives chosen from the employees of Yarmouk University. They were drawn by the snowball method, and a questionnaire was used as a tool to elicit their responses. The results indicated that there are statistically significant differences in the attitudes of females and males. They were in favor of males with regard to the division of gender roles in the family and the role of women in carrying out care and service tasks in the family such as raising children, cleaning, and feeding, while females' attitudes were negative towards these terms. There were also statistically significant differences regarding the attitudes towards the status of women in Jordanian society in favor of females, as they were more positive than males. Accordingly, the study recommends focusing on the subject of social status, how to exploit time, unpaid work, and possession of economic resources. The study also recommends reviewing the laws on inheritance and alimony to bridge the gender gap.
\end{abstract}

KEYWORDS: Unpaid work, Gender equality, Social status, Attitudes of husbands and wives

Received: Jul 19, 2020; Accepted: Aug 09, 2020; Published: Sep 22, 2020; Paper Id.: IJEEFUSAUG20204

\section{INTRODUCTION}

Division of labor in societies has been witnessed throughouthistory beginning with the prehistoric era when it was associated with the change of production means used by the society. Labor was divided between the two sexes based on place and time respects. So, hunting was assigned to men, and fruit collection to women. Such division was based on cultural and biological differences, which preferred woman to remain close to the home and children in order to take care, raise, and feed children as well asdo other household chores. This is because the woman is biologically a mother who gives birth to children and breastfeed them, hence her ability and willingness to carry out such tasks. On the other hand, the physical and psychological structure of men enabled them better to hunt, face risks and confront predators (Cluster, 1991).

This division is still followedin the present time with slight differences. However, no matter how different, it will relate to these areas; the internal field is for women and the external field for men. Thus, the unpaid domestic work, which falls under the category of care and service tasks for family members, was assigned to women, while the paid work that represents the source of livelihood for the family was assigned to men who used to be considered as the main breadwinner for the family (Engels, 1957).

Reviewing the unpaid work in the family, we notice that there is an effort that goes without pay,doing tasks that do not benefit their doers (women) in specific.For example, a woman's cleaning of the house is a work 
that all family members benefit from although she does not receive any payment for it. However, if she does not do it, another person will be hired to perform the cleaning service, and s/he willbe paid a certain amount of money that is determined by the amount of work, duration of completing the work and the market standards. Economics statistics in the world, and specifically in Arab world,shows that males have the largest share of ownership of material resources; including movable and immovable assets that a person can dispose of and benefit from. In fact, males control economics, paid labor force, political and social participation, possession of power, and leadership positions, and this is significantly greater than what women control in society. Moreover, the social status of men and their prestige in society is appreciated more than that of women in most societies all over the world (UN, 2019).

A global survey was conducted by the United Nations in 2019 to identify the role of women in development. The survey aimed to investigate the reasons behind women's poverty, which caused are caused by low income and lack of time for achieving sustainable development. The study,which is implemented by the United Nations General Assembly every five years, included several topics that have an impact on the woman's role in economy on national, regional and international levels. The study concluded that it is time to take an in-depth look at the ways in which poverty forms and constrains the life of women. Such poverty results from the inappropriate responsibility of women, compared to men, for bearing the burden of unpaid care work and household chores. These include direct care, direct contact, and emotional and psychological support, such as feeding a child or helping an elderly person to shower. The indirect care is represented by household work, such as cleaning and washing clothes. These two forms take a significant amount of women's time and effort. It is worth mentioning that women contribute to achieving human well-being and the production and sustain of productive workforce that is capable of learning and innovation. Such workforce is key factor for supporting economic growth (UN, 2019). These inappropriate responsibilities increase the vulnerability of women and girls to poverty as they make them less able to find paid work, achieve financial independency, accumulate savings, assets or pension income in the future. This is aggravated by the discriminatory social norms and gender stereotypes that perceive women as natural providers of care. The double dilemma of lack of time and income is particularly evident for the woman in herreproductive years asshe provides care for young children and their families' members, spending long time day hours doing so. That makesit impossible to find time to do paid work inside or outside the house. In addition, it becomes hard to find time for self-care and entertainment, which are key indicators of well-being (UN, 2019).

Because these activitiesare explicitly excluded from the national financial accounts, and then overlooked in the economic analyses of most countries in the world,the Sustainable Development Plan called for the necessity of recognizing and appreciating unpaid care and household chores and promoted the sharing of responsibility for these activities as formulated in the fifth objective of the fourth goal of the Plan (United Nations, 2019). It should be noted here that the progress made to achieve these goals and to overcome obstacles has been slow and confined to only few regions of the world where the gaps in participation in the workforce and employment has been decreased. The unequal distribution of unpaid care and domestic work between men and women and between families and society has been an important determinant of gender inequalities. The Plan focused on the importance of social protection for all and on taking measures to acknowledge unpaid domestic work and distribute it between family members. When this is done, we can achieve the purposes of the new sustainable development plan, which aimto reduce poverty and inequalities and achieve gender equality (ILO, 2016). 
This study aims to identify the attitudes of spouses in Jordanian families towards unpaid work and the possession of resources and its impact on the social status of men and women in the society.The study attempts to understand the current social attitude and come up with conclusions and recommendations that may contribute to changingthe woman's social status and reducing gender gap in all areas of sustainable development.

\subsection{Problem of the Study}

The problem of the study lies in identifying the attitudes of spouses in Jordanian families towards unpaid work and the possession of resources and its impact on the social status of men and women in the society. This is because these attitudes and their impact on the social structures and relationships are crucial for the individuals" and institutions' daily lives and because they affect people's behaviors, actions, interactions, role-plays, statuses, decisions and destiny.

\subsection{Study Objectives}

This study aims to identify theattitudes of Jordanian spousestowards unpaid work, the division of roles, tasks, and daily activities for both men and women in Jordanian households. Second, it seeks to find out their attitudes towards the possession of economic resources, controlling these resourcesand their impact on the social status of both women and men in the Jordanian society.

\subsection{Study Questions}

This study seeks to answer the following questions:Isthere any statistically significant differences in the attitudes of Jordanian spouses towards:

- The unpaid work in household, the division of roles, tasks and activities for both women and men.

- The possession of economic resources, controlling these resources and their impact on the social status of both women and men in the Jordanian society.

\subsection{Importance of the Study}

\section{This Study is important for Two Reasons:}

Theoreticalreasons:to the best of the researcher's knowledge, there are inadequate studies- on the domestic and regional levels- that concentrate on the attitudes of spouses towards unpaid work and social status.Previous research addressed women's work outside home.Other researchinvestigated the attitudes towards the status of women in some Arab countriesand focused on the roles of women, but these studies were not comprehensive.However,this study adds some knowledge to the relevant literature, which seeks to reach a greater knowledge about the Jordanian societyand gender and women studies, whichall seek to develop and promote social equality and justice.

Practical reasons:this study can be considered as a basis for drawing attention to the value of unpaid work women do in the field of care and services to all members of the family. Such work is, unfortunately, not recognized by the economy or society. In addition, the study attempts to reconsider the status of women in society by focusing on the relationship between this unpaid work, time and effort spent which women do for their families and society andhow it affectstheir social status compared to men. It is hoped that this study will become a trigger for change with regardto beliefs related to women's social status. 


\subsection{OperationalDefinitions}

Attitude: a number of motivational, emotional, cognitive and epistemic processes that have been organized in a permanent form and have started to determine the response of the individual to one aspect of his/her environment. Therefore, attitude indicates consistency, agreement and harmony among responses that allow us to predict a response to some social situations or issues (Sarri, 2016).

Paid work: the effort exerted during a certain period of time where the worker receives a certain amount of money to be paid by the person who provided this work to him. This money is granted as a wage or salary that is disbursed to the worker on daily, weekly, or monthly basis in exchange for his/her effort and time to implement or produce a specific good or service.

Unpaid work: the effort exerted during a certain period of time where the worker does not receive any money in return for his/her work. In other words, there is no reimbursement or compensation for his/her effort and time to implement or produce a specific good or service.

Economic resources: all assets or belongings that a person possesses which provides him/her with a movable or immovable amount of money (available in the form of cash or can be turned into cash in exchange for selling, leasing, mortgaging, or exchanging it). Therefore, economic resources can be cash money, bank balances, lands and various properties: apartments, homes, cars, furniture, machinery, and jewelry.

Control and disposal of Economic Resources: refers to the person's ability to determine the way in which the financial amounts he/she possesses will be spent, and his/her ability to make decisions to buy and sell various properties or any type of commercial transaction such as mortgage, security, exchange, transfer of property, and gift, at any time he/she wants, by any amount or value they define, and for any persons they wish to deal with, without any authority or interference from any of other persons aroundthem, and regardless of the degree of their relationship.

Social status: the respect or reputation related to the social status or social rank of an individual in a society; it is the rank or position by which a person is known in a society.

\section{LITERATURE REVIEW}

To the best of the researcher's knowledge, the spouses' attitudes toward unpaid work and possessing economic resources and their impact on the social status of both women and men in society is a topic that has been rarely studied if not neglected altogether. There are only few studies, but do not focus on the interconnectedness of these attitudes. On the other hand, there is some interest in this topic by international institutions and organizations, and there are some published reports on the parts of this topic in English. Below are some of the previous studies that dealt with the topic of the study.

Balawi and Moussaoui (2018) aimed to know the attitudes of students towards the social status of women in the Algerian society and the extent of the intervention of the gender variable and the place of residence of the studied sample in creating statistically significant differences towards the social status of women. The survey included 116 students from the Algerian University of May 8. The study concluded that there is a positive attitude towards the social status of women in the Algerian society and that there are statistically significant differences in the gender variable in favor of females whose statuses were more positive compared to men. In addition, there werestatistically significant differences of the place of residence as the attitudes of individuals of urban areas were more positive than those of individuals of rural areas. The 
researchers, thus, recommended the necessity of enhancing the status of women and their position in the Algerian society.

Gallup Inc. (2017)carried out in-depth interviews with adult women and men in 142 countries with a total of 149,000 persons, to identify their attitudes toward women in the workplace. The study concluded that $70 \%$ of women and $66 \%$ of men prefer wage-earning work for women. It also found that the most important challenges facing the work of women and men in developing countries is the extent to finding a balance between work and home. Unfair treatment at work came second followed by the lack of care homes for dependent relatives and children at reasonable prices and finally the gender wage gap. A quarter of the respondents indicated that despite their high contribution, in terms of income, to the household expenses, men still see themselves as the main source of income at home.

Al-Suwaiti (2016) investigated the respondents' attitudes towards the impact of gender factors, geographical background, education, and the family's monthly income on the social status of women in the Palestinian society, whether at home or at work, and their opinions towards mixing with men, and towards women's rights. A sample of 171 A students from the universities of Hebron and Bethlehem in Palestine participated in the study which concluded that there are no differences that can be related to the variable of education. However, there was a significant difference according to the 'geographical background'variable, i.e. the parents' place of birth in Palestine or outside it. In fact, those whose parents were born in Palestine had a positive attitude for the work of women and mixing with men with statistically significant difference in favor of females. Finally, it was also found out that there were significant differences related to the gender variable in favor of females which indicated that females view their gender as better than males' views.

The Jordanian Department of General Statistics (2016) conducted a study to conclude the results of the Population and Housing Census of 2015. The study attempted to provide data and indicators to measure the status of women in the Jordanian society and the size of the gender gap between women and men in all economic and social areas. Three main issues were included: 1- Women's work and challenges related to women which are an important factor towards achieving a great deal of equality in the distribution of revenues, decisions, and roles within the family and society in general. 2Women's access to and control over economic resources, 3- Early marriage.The results of the study were the starting point for this study. The study found that the efforts that have been made and are still being made in order to increase the integration of women in Jordanian economic life are still below the required level. Notably, the weak role of women in economic life is one of the main problems facing the national economy. This puts pressure on the productivity of the Jordanian economy and deprives it from potential and unexploited economic potentials and capacities, which increases dependency ratios in the Jordanian society. In addition, the marginalization of women's participation in areas related to society and the economic, social and other areas had negative effects on her status and roles that were expected to be achieved if she had been able to obtain opportunities of participation in an equal manner to men. Theaccess to resources is defined as providing opportunities for women to own economic resources (lands, apartments, bank balances, and even benefit from educational opportunities) and to enhance their ability to make decisions regarding the disposal of these resources, and to control their economic assets. These all have effect on enhancing the living and economic status of women and a direct relationship withwomen's social status.

Al-Mayali (2014) aimed to identify the behavioral values that affect the position of Iraqi women and how women work to materialize these values. To this end, the researcher used a questionnaire to measure these values. The study concluded that the most valuable value that a woman should have, in order to have a place in the Iraqi society, is patience by which she gains respect of her spouse, family and society. The second value is management asa woman who can 
manage herselfeconomically can manage her family and household. Then comesthe value of the work, as the woman would persist to raise her children and help her husband if he were unable to afford all the requirements of life. Such a woman will be respected and have a clear statusin her family and the community.

Al-Hammadi and Al-Zubaidi (2012)conducted a study to find out the global components towards women's work, society's perception, women's roles and the material aspect of women's work. The study attempted to find out the level of such attitudes and how significant the differences towards the work of women arein light ofgender and workplace variables. A random sample of 172 people (108 males, 64 females) from the Emirati army and police- UAE- was chosen. The results concluded that there are statistically significant differences according to genderin favor of male participantswho had negative view towards the society's perception of women's work, their roles and the material aspect of their work.

Thebaud (2010) sought to explore the differences between nations in terms of the effect of men's income on the exclusivity of their wives to bear household burdens. Using the International Social Survey Program and the data of eighteen participating countries, the study pinpointed the expectations related to masculinity with regard to males' involvement and their contribution to household burdens. It also indicated the importance of cultural contexts for understanding the relationship between paid and unpaid work in different societies since they differ according to gender expectations in each of them.

Al-Majali (2002) aimed to identify the role and status of Bedouin women in the Southern Badia in light of the social, economic, cultural and political changes and transformations that affected the Bedouin community in general and the Bedouin women in particular. In addition, the study investigated the factors that contributed to the change in women's roles, and tried to identify the obstacles that stand in the way of their progress and development in order to understand the reality, role, and status of Bedouin women. The study concluded that the low family size, high level of illiteracy, and early marriage for women resulted in the majority of women in the sample being housewives. She also clarified that there is a change in the status and role of women compared to the past due to the policy of settlement, the spread of education, the availability of work opportunities, and the spread of modern media that contributed to this positive change in women's role and status. The researcherpointed to the necessity of carrying out multiple studies and research regarding the position of women in all regions in order to reach different individuals and cultures and to use various methods to reach understanding of this very important issue.

Al_Mujaydal (2002) investigated the university students 'attitudes towards women's work and the extent of differences in attitudes according to gender. The study included 200 students who were randomly chosen and a questionnaire was used to measure their attitudes. The study found out that there are statistically significant differences in attitudes towards women working in favor of females compared to males. However, the results did not show significant differences according to the university specialization.

In light of the above, the current study is different from the previous studies in the following:

- The previous Arabic studies focused on aspects related to women's unpaid work, but they addressed this issue as secondary one or as proof for the importance of women's work, and linkedit to women's economic or productive participation and other topics. However, unlike foreign studies, none of theArabic studies focused on the relation between women's work and their social statusin society. 
- Most of the studies focused on investigating the attitudes of university students towards the social status of women. This study, by contrast, is specifically concerned with the attitudes of husbands and wives in Jordanian families towards unpaid work and the possession of economic resources for both of them, and how this affects the status of each of them in the Jordanian society.

\section{METHODOLOGY AND PROCEDURES}

\subsection{Method}

This study used the descriptive approach, which relies primarily on studying the phenomenon through monitoring its characteristics and analyzing it to obtain accurate and sufficient data about it. This allows the researcher to make generalization and predictions, and thus this approach is appropriate for our study (Al-Najjar et al., 2010).

\subsection{Study Population}

The study population includes wives and husbands in Jordanian families in the Irbid governorate was chosen due to the researchers' limited budget allocated to the study, and the high cost of covering areas far from the researchers' place of residence. The report of the Jordanian Department of General Statistics titled "Estimated Population of the Kingdom by Governorate, Gender and Families for the Year 2018" indicates that the number of families in Irbid Governorate was 384010; 111930 families reside in the city of Irbid, and 272,080 families live in villages and suburbs. The report also indicated that the total number of females in families within the city of Irbid reached 259,483 in comparison to 283,401 males (Jordanian Department of General Statistics, 2018).

\subsection{Study Sample}

Due to the large size of the study population and its spread throughout Irbid governorate, a Snowball Sample was adopted. This is a random sample whose results cannot be generalized but gives sufficient indicatorsabout the phenomenon under question (Al-Najjar et al., 2010).A person is chosen and he/she will lead the researcher(s) to someone who meets the specifications and standards of the target group and so on. The standards of the chosen persons are as follows:

- Jordanian husband/ wife

- 2 - The subject currently resides in his/her family with (his/her spouse) permanently. This does not include the divorced, widowed and separated nor the families in which the husband/ wife has travelled outside the country, or lives in a separate place).

- There are children living with them in their families (regardless of their gender or age).

- One of the spouses or both has a paid work.

- The respondent does not employ a servant/ maid on a daily, weekly, or monthly basis. This indicates that a family member, some of them or all of them carry out all the household tasks. In other words, they perform all the tasks of their daily life and the services they need in terms of cooking, cleaning and care-related tasks which have been explained in detail in the section of the study tool. The questionnaire was distributed to 160 male and female respondents from Yarmouk University, butonly 142 acceptable questionnaires were retrieved for analysis.

Table (1) shows the characteristics of the research sample. The percentage of participants from the age group (3555) was the highest, as $78 \%$ : 37 males and 74 females. As for the category (55 years and above), they accounted for 20\%: 27 males and 2 females, and $1 \%$ of the category (25-35). 
Table 1: Sample Characteristics

\begin{tabular}{|c|c|c|c|c|c|}
\hline \multirow{2}{*}{\multicolumn{2}{|c|}{ Sample Demographic Data }} & \multicolumn{2}{|c|}{ sex } & \multirow[b]{2}{*}{$\%$} & \multirow{2}{*}{ Total } \\
\hline & & $\mathbf{M}$ & $\mathbf{F}$ & & \\
\hline \multirow{3}{*}{ Age } & 25 to $<35$ & 1 & 1 & $1 \%$ & 2 \\
\hline & 35 to $<55$ & 37 & 74 & $78 \%$ & 111 \\
\hline & $\geq 55$ & 27 & 2 & $20 \%$ & 29 \\
\hline \multicolumn{2}{|r|}{ Total } & 65 & 77 & $100 \%$ & 142 \\
\hline \multirow{3}{*}{ Family\# } & 2 to 3 & 2 & 9 & $8 \%$ & 11 \\
\hline & 4 to 5 & 34 & 65 & $70 \%$ & 99 \\
\hline & 6 to 7 & 29 & 3 & $23 \%$ & 32 \\
\hline \multicolumn{2}{|r|}{ Total } & 65 & 77 & $100 \%$ & 142 \\
\hline \multirow{4}{*}{ Education } & $\leq$ high school & 0 & 1 & $1 \%$ & 1 \\
\hline & Diploma & 18 & 5 & $4 \%$ & 5 \\
\hline & B.A & 43 & 64 & $64 \%$ & 91 \\
\hline & \begin{tabular}{|l} 
High Education \\
\end{tabular} & 4 & 0 & $3 \%$ & 4 \\
\hline \multicolumn{2}{|r|}{ Total } & 65 & 77 & $100 \%$ & 142 \\
\hline
\end{tabular}

The highest percentage of respondents $(70 \%)$ came from families with $4-5$ members. $23 \%$ came from families with6-7 members. The lowest percentage (8\%)came from families with only 2-3 members. People with a bachelor's degreeaccounted for $64 \%$ of the participants, followed by those who hold a diploma and postgraduate degree, $4 \%$ and $3 \%$ respectively. $1 \%$ of participants had a high school diploma or less.

\subsection{Study Tool}

A 'questionnaire' was used to collect data and information from the respondents, and was distributed by the researcher and another group of qualified graduate students in a confrontational way. The questionnaire consisted of three parts; the first part represents the personal information of the respondents (demographic characteristics: gender, age, educational level, job). The second part included a measure of attitudes, which included 27 statements. The measure aimed to investigate the attitudes of husbands and wives regarding the divisions and tasks performed by both men and women through the day and in their free time, i.e. it includes a description of how they use their time and the nature of the work they do, whether paid or unpaid (Homecare and Services). The Likert scale was used to determine attitudes according to their gradesas follows: 1-Strongly Disagree, 2- Disagree, 3- Neutral, 4- Agree, 5- Strongly Agree. The third part of the questionnaireconsisted of 34 statements that aim to measure the attitudes of husbands and wives towards owning economic resources and their relationship to the social status of both men and women in the society, again using Likert scale.

\subsection{Validity and Reliability}

The questionnaire was reviewed by a number of professors in the faculties of media, arts and education at Yarmouk University. They provided their judgment on the validity and reliability of the questionnaire, and its suitability for the subject of the study. After retrieving the questionnaires from the reviewers, their observations were taken into consideration and the questionnaire was adjusted accordingly to make the study tool suitable. To ensure the consistency of the tool, the questionnaire was re-applied to (35) individuals as a pilot group, which was not included in the original sample of this study. The value of Alpha Cronbach coefficient was (73\%), which indicates a high level of consistency.

\section{RESULTS}

The researchers used the Social Sciences Statistical Package (SPSS) to analyze the data which were reviewed, checked and tabulated. They were, then, processed statistically by finding out percentages, means, standard deviations and T-tests to 
measure the differences between the means. The aim was to answer the study question: "Are there statistically significant differences between husband and wife attitudes in the Jordanian family towards unpaid work in the family, the division of roles, unpaid tasks and activities for both men and women and the social status of both men and women in the Jordanian society?" Likert scale was used to identify the responses according to the following:

Table 2: Response Category and Attitude Description

\begin{tabular}{|r|c|r|}
\hline \multicolumn{1}{|c|}{ Category } & Mean range & Attitude description \\
\hline Very weak & $1-1.49$ & Very negative \\
\hline Weak & $1.5-2.49$ & negative \\
\hline Satisfactory & $2.5-3.49$ & neutral \\
\hline Good & $3.5-4.49$ & Positive \\
\hline Very good & $4.5-5$ & Very positive \\
\hline
\end{tabular}

To answer the first part of the question: Are there statistically significant differences between husband's and wife's attitudes' in the Jordanian family towards unpaid work in the family, the division of roles, unpaid tasks and activities for both men and women? The results of the statistical analysis in Table (3) indicate a statistically significant difference in the attitudes of the male and female respondents as alpha was 0.001 with means of 3.2467 and 2.7879 respectively. The resultswere very positive in favor of males towards unpaid work and the division of roles, tasks and household chores, pastime and leisure of both husband and wife. However, results were very negative for females in the same fields.

Table 3: Attitude Differences regarding unpaid work, the division of roles, tasks and household chores, pastime and leisure of both husband and wife

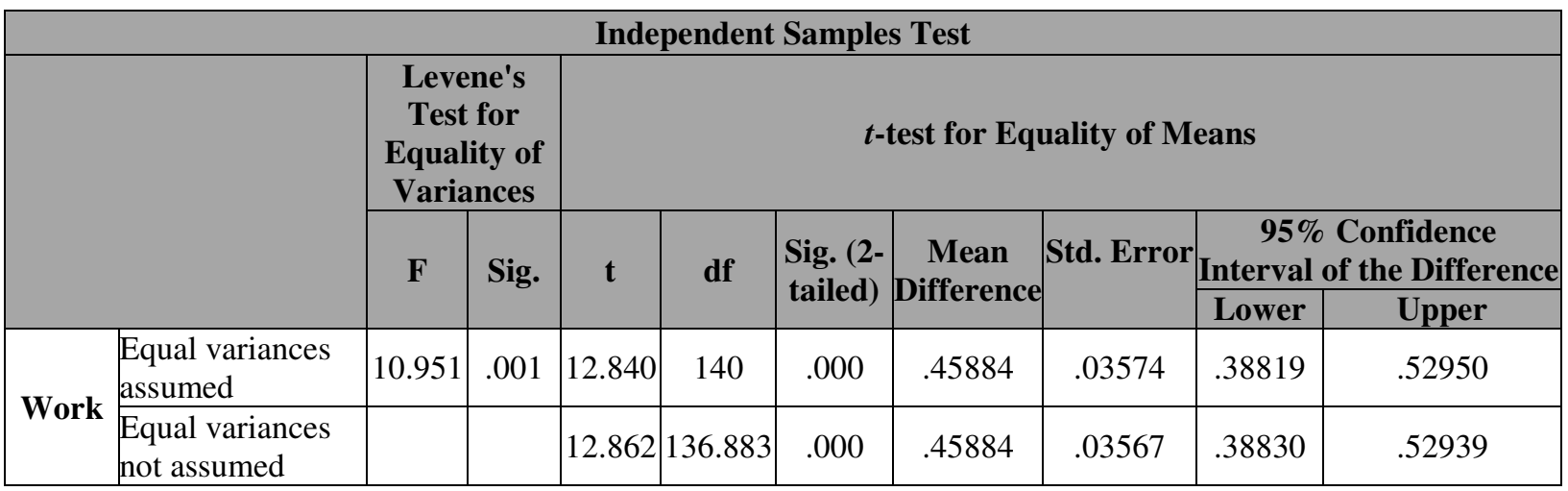

Table 4: Means Differences

\begin{tabular}{|c|c|c|c|c|c|}
\hline \multicolumn{7}{|c|}{ Group Statistics } \\
\hline & Sex & N & Mean & Std. Deviation & Std. Error Mean \\
\hline \multirow{2}{*}{ Work } & M & 65 & 3.2467 & .20985 & .02603 \\
\cline { 2 - 6 } & F & 77 & 2.7879 & .21408 & .02440 \\
\hline
\end{tabular}

Based on the statements' analysis and differences mentioned above, attitudes were divided into two categories:

Positive Attitudes: Males had positive attitudes towards unpaid work that includes division of labor, household tasks and care and service roles of all family members including caring for children, raising them and caring for the elderly, and everything related to the internal space. By analyzing the relevant statements, males seem to considerthat a female space. Means and differences in attitudeswere related to unpaid work, roles and women household tasks, pastime and leisure time associated with unpaid as well as paid work for each of them. The results showed that the males had means that ranged 
between 3.50 and 4.29 and these are considered very positive as shown in Table (5):

Table 5: Means and Attitude Differences for Statements related to 'division of work and use of Time'

\begin{tabular}{|c|c|c|c|c|c|c|c|c|c|c|c|c|}
\hline$\#$ & Statement & 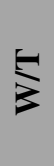 & 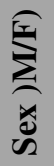 & 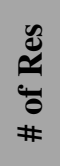 & 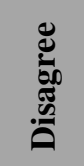 & $\begin{array}{l}\mathscr{E} \\
\stackrel{4}{*} \\
\ddot{\sigma} \\
\#\end{array}$ & 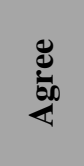 & 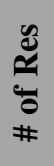 & 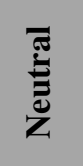 & हี & 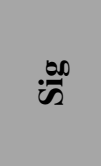 & 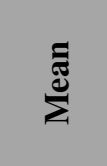 \\
\hline \multirow[b]{2}{*}{19} & \multirow{2}{*}{$\begin{array}{l}\text { The woman is solely responsible for } \\
\text { following up on the study of children, } \\
\text { their schoolwork, and exams }\end{array}$} & \multirow[b]{2}{*}{ W } & $\mathrm{M}$ & 6 & 0.09 & 59 & 0.91 & 0 & - & 65 & \multirow[b]{2}{*}{0.000} & 4.2923 \\
\hline & & & $\mathrm{F}$ & 38 & 0.49 & 31 & 0.40 & 8 & 0.10 & 77 & & 2.8831 \\
\hline \multirow[b]{2}{*}{18} & \multirow{2}{*}{$\begin{array}{l}\text { The woman is solely responsible for } \\
\text { caring for the nutrition and food of all } \\
\text { family members }\end{array}$} & \multirow[b]{2}{*}{$\mathrm{W}$} & $\mathrm{M}$ & 3 & 0.05 & 59 & 0.91 & 3 & 0.05 & 65 & \multirow[b]{2}{*}{0.000} & 4.2308 \\
\hline & & & $\mathrm{F}$ & 12 & 0.16 & 64 & 0.83 & 1 & 0.01 & 77 & & 3.6753 \\
\hline \multirow[b]{2}{*}{13} & \multirow{2}{*}{$\begin{array}{l}\text { The woman is responsible for cleaning } \\
\text { the house, clothes, all furniture and } \\
\text { rooms of the house }\end{array}$} & \multirow[b]{2}{*}{$\mathrm{W}$} & $\mathrm{M}$ & 2 & 0.03 & 61 & 0.94 & 2 & 0.03 & 65 & \multirow[b]{2}{*}{0.004} & 4.2000 \\
\hline & & & $\mathrm{F}$ & 4 & 0.05 & 73 & 0.95 & 0 & - & 77 & & 3.8831 \\
\hline \multirow{2}{*}{5} & \multirow{2}{*}{$\begin{array}{l}\text { In my spare time, I go to entertainment } \\
\text { centers and cafes with my friends }\end{array}$} & \multirow{2}{*}{$\mathrm{T}$} & $\mathrm{M}$ & 2 & 0.03 & 62 & 0.95 & 1 & 0.02 & 65 & \multirow{2}{*}{0.000} & 4.1538 \\
\hline & & & $\mathrm{F}$ & 32 & 0.42 & 4 & 0.05 & 41 & 0.53 & 77 & & 2.6753 \\
\hline \multirow[b]{2}{*}{20} & \multirow{2}{*}{$\begin{array}{l}\text { The woman is responsible for taking } \\
\text { care of her husband, entertaining him } \\
\text { and caring for his requirements }\end{array}$} & \multirow[b]{2}{*}{ W } & $\mathrm{M}$ & 7 & 0.11 & 57 & 0.88 & 1 & 0.02 & 65 & \multirow[b]{2}{*}{0.005} & 4.0923 \\
\hline & & & $\mathrm{F}$ & 13 & 0.17 & 63 & 0.82 & 1 & 0.01 & 77 & & 3.6104 \\
\hline \multirow{2}{*}{6} & \multirow{2}{*}{$\begin{array}{l}\text { In my spare time, I go on trips to various } \\
\text { tourist places with my family }\end{array}$} & \multirow{2}{*}{$\mathrm{T}$} & $\mathrm{M}$ & 1 & 0.02 & 53 & 0.82 & 11 & 0.17 & 65 & \multirow{2}{*}{0.000} & 4.0615 \\
\hline & & & $\mathrm{F}$ & 1 & 0.01 & 74 & 0.96 & 2 & 0.03 & 77 & & 3.9740 \\
\hline \multirow[b]{2}{*}{3} & \multirow{2}{*}{$\begin{array}{l}\text { All tasks outside the home are the } \\
\text { responsibility of the man and he is best } \\
\text { suited to do them }\end{array}$} & \multirow[b]{2}{*}{ W } & $\mathrm{M}$ & 4 & 0.06 & 55 & 0.85 & 6 & 0.09 & 65 & \multirow[b]{2}{*}{0.000} & 3.9231 \\
\hline & & & $\mathrm{F}$ & 34 & 0.44 & 41 & 0.53 & 2 & 0.03 & 77 & & 3.0779 \\
\hline \multirow[b]{2}{*}{4} & \multirow{2}{*}{$\begin{array}{l}\text { The woman is fully responsible for } \\
\text { raising children and she is best suited } \\
\text { for this }\end{array}$} & \multirow[b]{2}{*}{ W } & $\mathrm{M}$ & 12 & 0.18 & 51 & 0.78 & 2 & 0.03 & 65 & \multirow[b]{2}{*}{0.000} & 3.8769 \\
\hline & & & F & 43 & 0.56 & 34 & 0.44 & 0 & - & 77 & & 2.8701 \\
\hline
\end{tabular}

$* * *$ statistically significant at $\alpha \leq 0.05$

The results also showed that females' attitude was positive towards statements related to time and ways of using it in negative ways, as their answers were strongly agree and agree with means ranging between 3.818and 4.792) as indicated in Table (6).

Table 6: Means and attitude differences of females most positive statements related to 'division of work and use of

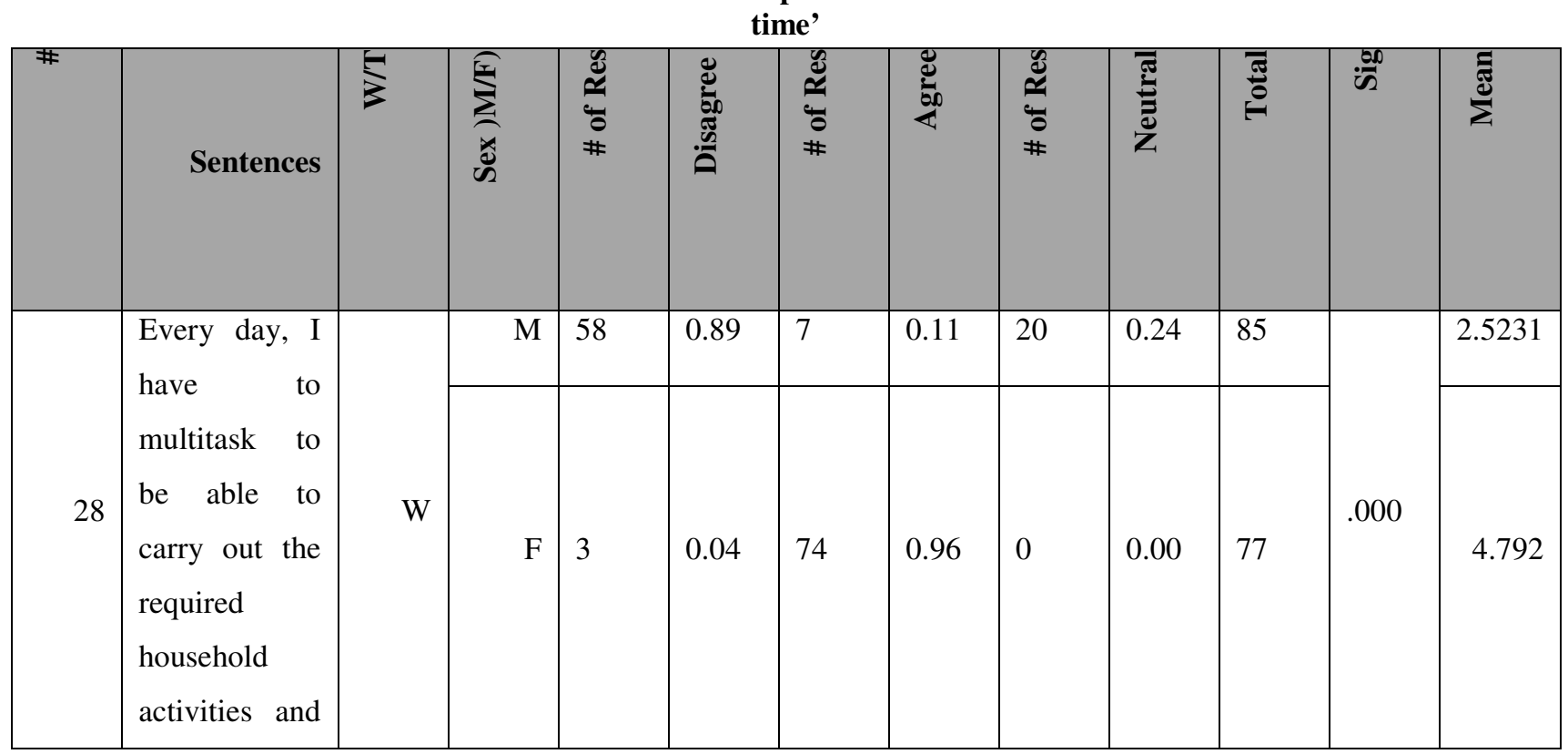




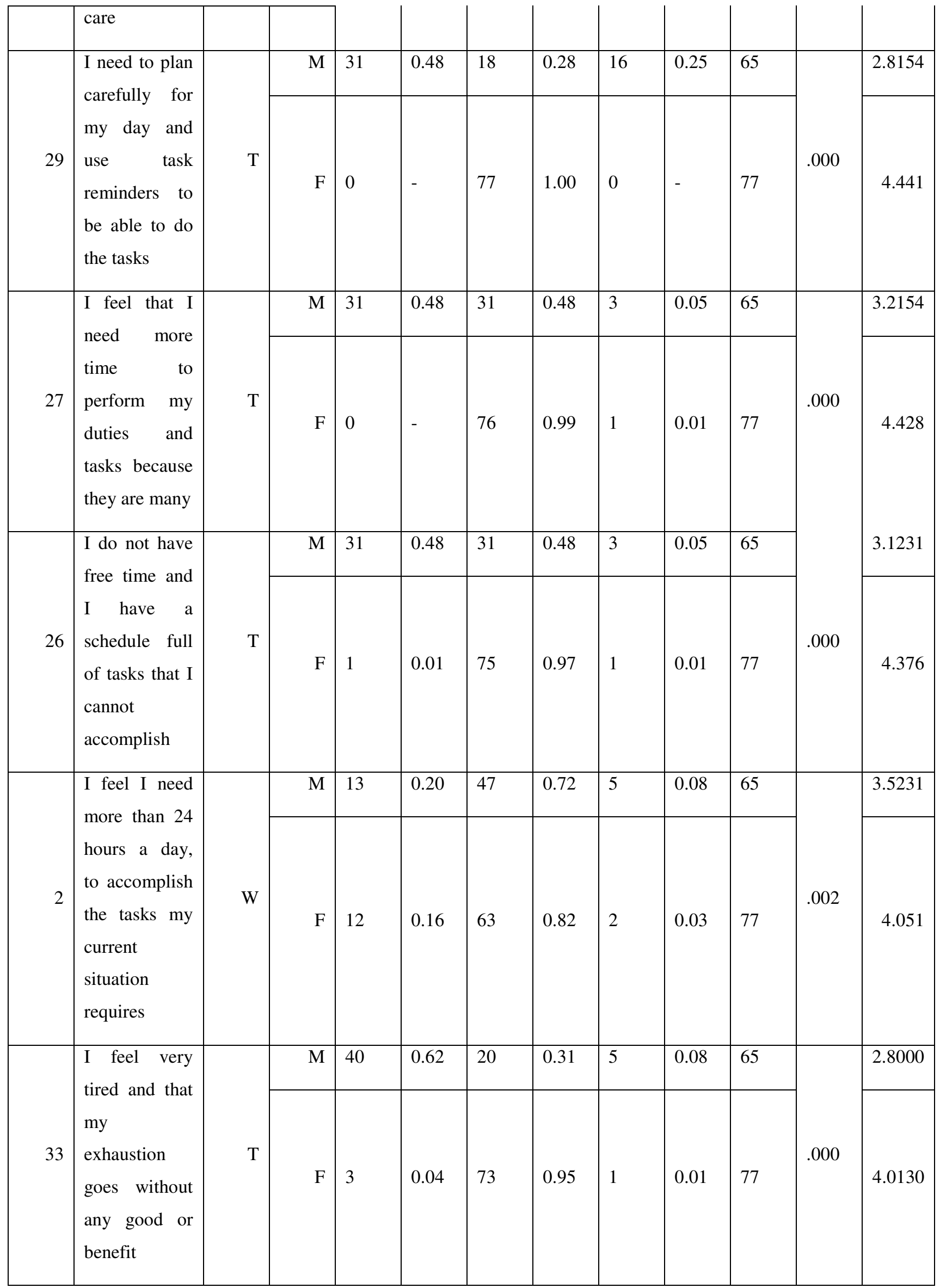




\begin{tabular}{|c|l|l|l|l|l|l|l|l|l|l|}
\hline & $\begin{array}{l}\text { The woman is } \\
\text { responsible } \\
\text { for cleaning } \\
\text { the house, } \\
\text { clothes, all } \\
\text { furniture and } \\
\text { rooms of the } \\
\text { house }\end{array}$
\end{tabular}

**** statistically significant at $\alpha \leq 0.05$

The results indicated that the highest statement was that they have to perform multitask in order to be able to accomplish the required household activities and care, with a mean of $(4,782)$. Then,the statement 'they need to plan carefully for my day and use task reminders to be able to do the tasks' with a mean of $(4,441)$ and so on and so forth. The value of $\alpha$ of all statements was between $(0.000-0.002)$ and all of them indicate statistically significant differences between the attitudes of both males and females in the studied sample.

As for the division of labor, tasks and roles in the family, their attitude was positive towards the statements that focused on the woman's exclusivity for the roles of care, nutrition, food, care for the husband, entertaining him and paying attention to his requirements, and they were statistically significant as $\alpha$ was $(0.004,0.00$ and 0.005$)$ respectively and with means of $(3,883,3,675$ and 3,610$)$, respectively.

Negative Attitudes: The results showed that the females were negative towards the same statements mentioned above. The answers ranged from strongly disagree and disagree, to most of the statements that focused on the role of women in the home, the tasks and roles of care and service for family members, responsibilities of children's education, cleaning, cooking, caring for the spouse and children and the elderly. They also disagreed to the statementsthat these tasks are her responsibility and should not be shared the man as they are more suited for inner space ( $\operatorname{mean}=1.324)$. They had, further, very negative attitudes towards not having enough free time,as they believed that 24 hours a day is not enough to perform the tasks and burdens assigned to them. By comparison, maleshadnegative attitude, means ranged from 1.4 to 2.47, towards the statements that the man is responsible for caring for the children and cleaning the house.

On the other hand, there were NO significant differences with regard to the following statements:

- 'There is no discrimination in the tasks and activities assigned to men and women in paid jobs, and their nature is similar and identical'. The value of alpha was (0.598), and the answers were mostly disagreefor both sexes with means of (1.815) for males and (1.753) for females).

- 'My time is not mine, and I perform tasks to serve and care for others without any payment, and I enjoy it'. Alpha was 0.776 and 0.111 respectively, and means were 2.961 and 2.04 respectively.

- 'The man should be fully responsible for the provision of livelihood (income) for the family'. Alpha reached 0.514 , with a mean of 3.092 for males and 2.974 for females.

- 'All work inside the home is the responsibility of women as she is best suited to do them'. The value of alpha was 0.812 and with a mean of 2.830 for males and 2.883 for females. 
- 'The man is fully responsible for the follow-up on his children's study, cleaning the house and other household and service tasks, and he is fully responsible for raising children, as he is most suited for that'. Alpha was 0.057 , and means were 0.615 and 0.101 , respectively.

To answer the second part of the question: "Are there statistically significant differences in husband and wife attitudes in the Jordanian family towards possessing and controlling of economic resources and the association of these with the social status of both women and men in Jordanian society?

The results of the statistical analysis indicate that there are statistically significant differences in the attitudes of both males and females towards the possessing and controlling of economic resources and the association of these with the social status of both women and men in Jordanian society. The mean reached 2.721 for males and 3.163 for females. Table

(7) shows the differences in the means of attitudes for both women and men.

Table 7: Means Differences towards the possessing and controlling of economic resources and the association of these with the social status of both women and men in Jordanian society

\begin{tabular}{|l|c|c|c|c|c|}
\hline \multicolumn{6}{|c|}{ Group Statistics } \\
\hline & sex & $\mathbf{N}$ & Mean & Std. Deviation & Std. ErrorMean \\
\hline \multirow{2}{*}{ Status } & M & 65 & 2.7217 & .23644 & .02933 \\
\cline { 2 - 6 } & F & 77 & 3.1631 & .11924 & .01359 \\
\hline
\end{tabular}

Table (8) indicates statistically significant differences according to the statements that address the social and cultural causes that lead to increasing the gender gap in possessing and controlling resources, enjoying the rights and exercising them, the relationship of men and women in the society and their economic, political and social participation, and the reflection of these all on their social status.

Table 8: Attitude Differences regarding the possession and control of economic resources and their reflection on the social status of both women and men in Jordanian Society

\begin{tabular}{|c|c|c|c|c|c|c|c|c|c|}
\hline \multicolumn{10}{|c|}{ Independent Samples Test } \\
\hline & $\begin{array}{r}\text { Leve } \\
\text { Test } \\
\text { Equal } \\
\text { Varia }\end{array}$ & $\begin{array}{l}\text { ne's } \\
\text { for } \\
\text { ty of } \\
\text { nces }\end{array}$ & \multicolumn{7}{|c|}{ t-test for Equality of Means } \\
\hline & \multirow[t]{2}{*}{$\mathbf{F}$} & \multirow[t]{2}{*}{ Sig. } & \multirow[t]{2}{*}{$\mathbf{t}$} & \multirow[t]{2}{*}{ df } & \multirow[t]{2}{*}{$\begin{array}{l}\text { Sig. (2- } \\
\text { tailed) }\end{array}$} & \multirow[t]{2}{*}{$\begin{array}{c}\text { Mean } \\
\text { Difference }\end{array}$} & \multirow[t]{2}{*}{$\begin{array}{l}\text { Std. Error } \\
\text { eDifference }\end{array}$} & \multicolumn{2}{|c|}{$\begin{array}{c}\text { 95\% Confidence } \\
\text { Interval of the } \\
\text { Difference }\end{array}$} \\
\hline & & & & & & & & Lower & Upper \\
\hline \begin{tabular}{|l|l} 
Equal \\
variances \\
assumed
\end{tabular} & 59.81 & .000 & -14.36 & 140 & .000 & -.44138 & .03073 & -.50213 & -.38064 \\
\hline \begin{tabular}{|l|l} 
Status & Equal \\
& variances not \\
assumed
\end{tabular} & & & 13.65 & 90.90 & .000 & -.44138 & .03232 & -.50559 & -.37718 \\
\hline
\end{tabular}

Table 9 indicates the differences in the attitude of both males and females towards the statements that relate to possessing and controlling of economic resources and its relationship to the social status of both sexes. It also shows the means that show that the female attitudes are more positive towards the status of women and the reasons behind their current situation in the society with regard to their social, political and economic participation. 
Table 9: The females' most positive means and the differences in attitudes to the statements related to possessing and controlling of economic resources and its relationship to the social status of both women and men in the

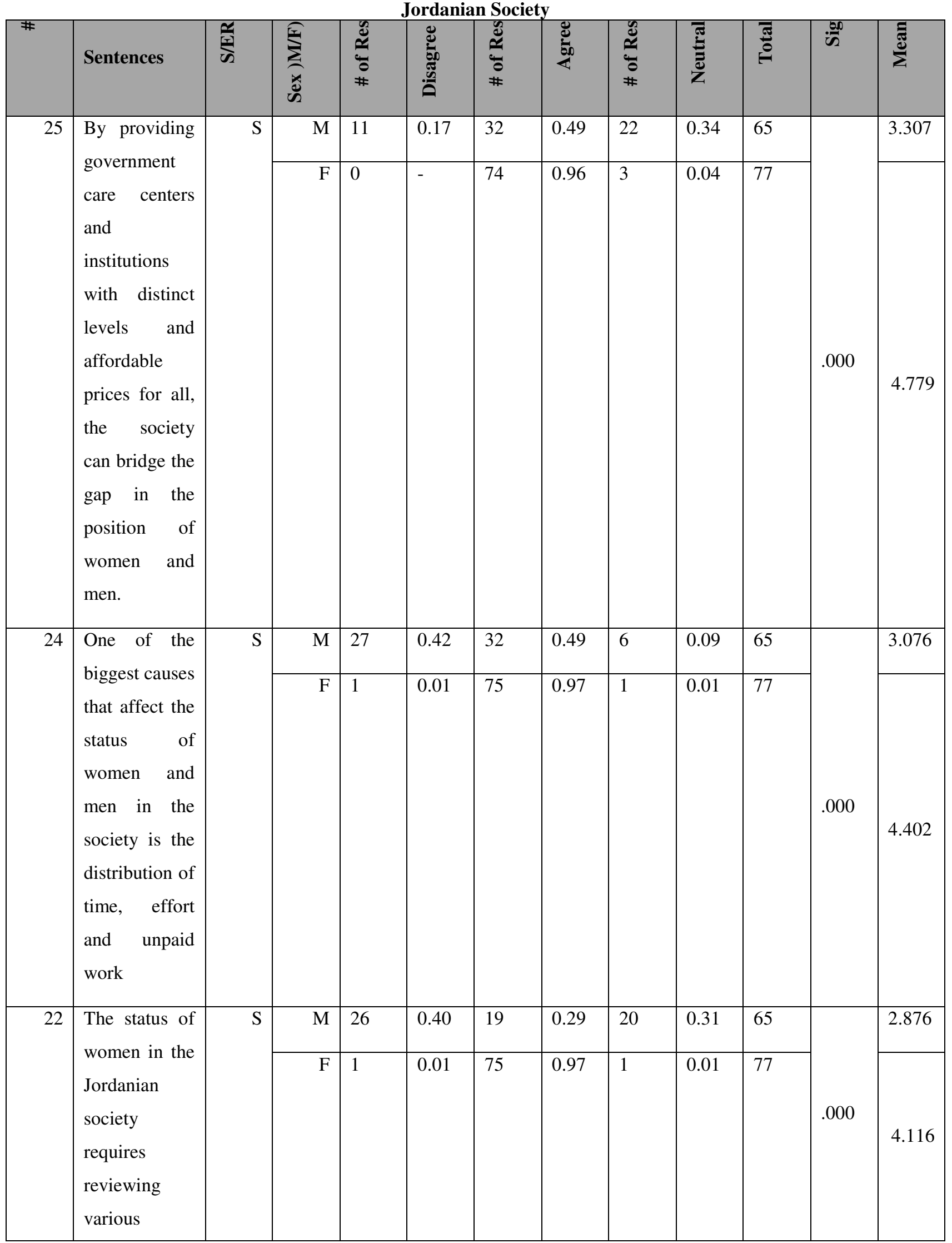




\begin{tabular}{|c|c|c|c|c|c|c|c|c|c|c|c|c|}
\hline & $\begin{array}{l}\text { policies, } \\
\text { regulations, } \\
\text { laws, and a } \\
\text { major change } \\
\text { to live up to } \\
\text { the level of } \\
\text { the status of } \\
\text { men }\end{array}$ & & & & & & & & & & & \\
\hline \multirow[t]{2}{*}{9} & \multirow[b]{2}{*}{$\begin{array}{l}\text { A woman } \\
\text { must obtain } \\
\text { the approval } \\
\text { of her } \\
\text { husband or } \\
\text { male family } \\
\text { members, } \\
\text { even if she } \\
\text { possesses } \\
\text { economic } \\
\text { resources in } \\
\text { order to be } \\
\text { able to } \\
\text { dispose of her } \\
\text { property (i.e. } \\
\text { buying and } \\
\text { selling) }\end{array}$} & \multirow[t]{2}{*}{ ER } & M & 13 & 0.20 & 49 & 0.75 & 3 & 0.05 & 65 & & 4.061 \\
\hline & & & $\mathrm{F}$ & 37 & 0.48 & 40 & 0.52 & 0 & - & 77 & .000. & 2.987 \\
\hline \multirow[t]{2}{*}{5} & \multirow[b]{2}{*}{$\begin{array}{l}\text { Alimony law } \\
\text { and } \\
\text { regulations } \\
\text { are the reason } \\
\text { why females } \\
\text { in the society } \\
\text { do not } \\
\text { possess } \\
\text { economic } \\
\text { resources }\end{array}$} & \multirow[t]{2}{*}{ ER } & $\mathrm{M}$ & 4 & 0.06 & 38 & 0.58 & 23 & 0.35 & 65 & & 3.507 \\
\hline & & & $\mathrm{F}$ & 0 & - & 75 & 0.97 & 2 & 0.03 & 77 & .000 & 3.974 \\
\hline \multirow[t]{2}{*}{6} & \multirow{2}{*}{$\begin{array}{l}\text { The reason } \\
\text { why a large } \\
\text { percentage of }\end{array}$} & \multirow[t]{2}{*}{ ER } & $\mathrm{M}$ & 45 & 0.69 & 11 & 0.17 & 9 & 0.14 & 65 & \multirow{2}{*}{.000} & 2.446 \\
\hline & & & $\mathrm{F}$ & 1 & 0.01 & 74 & 0.96 & 2 & 0.03 & 77 & & 3.974 \\
\hline
\end{tabular}




\begin{tabular}{|c|c|c|c|c|c|c|c|c|c|c|c|c|}
\hline & $\begin{array}{l}\text { females in } \\
\text { Jordan do not } \\
\text { possess } \\
\text { economic } \\
\text { resources is } \\
\text { because they } \\
\text { are not } \\
\text { involved in } \\
\text { the labor } \\
\text { market, and } \\
\text { thus, they do } \\
\text { not get paid } \\
\text { work }\end{array}$ & & & & & & & & & & & \\
\hline 7 & The reason & ER & $\mathrm{M}$ & 13 & 0.20 & 47 & 0.72 & 5 & 0.08 & 65 & & 3.507 \\
\hline & $\begin{array}{l}\text { that a large } \\
\text { proportion of } \\
\text { females in } \\
\text { Jordan do not } \\
\text { possess } \\
\text { economic } \\
\text { resources is } \\
\text { because they } \\
\text { exclusively } \\
\text { perform the } \\
\text { unpaid home } \\
\text { work }\end{array}$ & & $\mathrm{F}$ & 1 & 0.01 & 75 & 0.97 & 1 & 0.01 & 77 & .000 & 3.961 \\
\hline \multirow[t]{2}{*}{34} & \multirow[b]{2}{*}{$\begin{array}{l}\text { I feel that } \\
\text { how I spend } \\
\text { my time } \\
\text { affects my } \\
\text { health and } \\
\text { well-being } \\
\text { without } \\
\text { respect and } \\
\text { appreciation } \\
\text { for this effort } \\
\text { from my } \\
\text { family and }\end{array}$} & \multirow[t]{2}{*}{$\mathrm{S}$} & $\bar{M}$ & 28 & 0.43 & 34 & 0.52 & 3 & 0.05 & 65 & & 2.923 \\
\hline & & & $\mathrm{F}$ & 5 & 0.06 & 71 & 0.92 & 1 & 0.01 & 77 & .000 & 3.948 \\
\hline
\end{tabular}




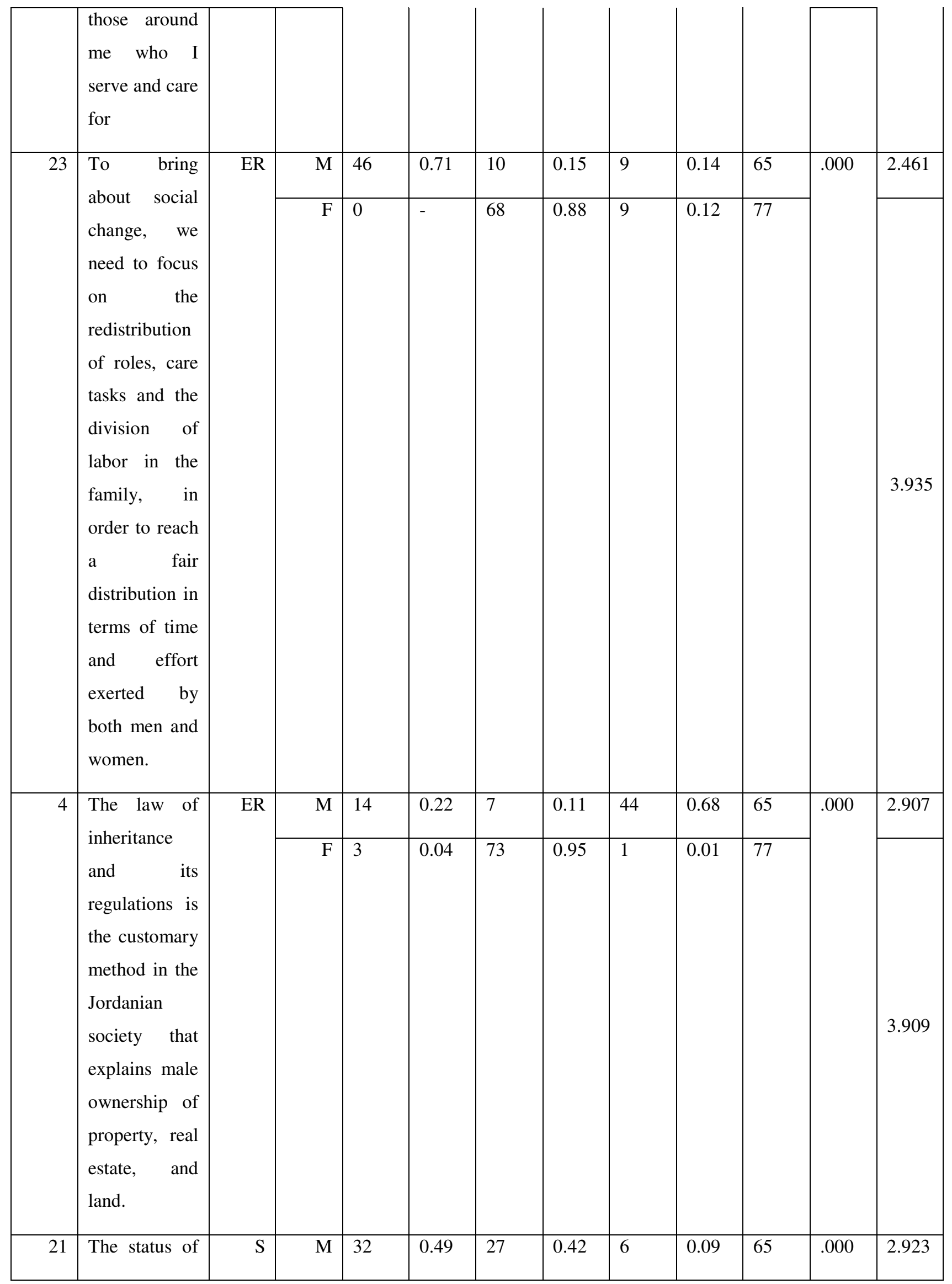




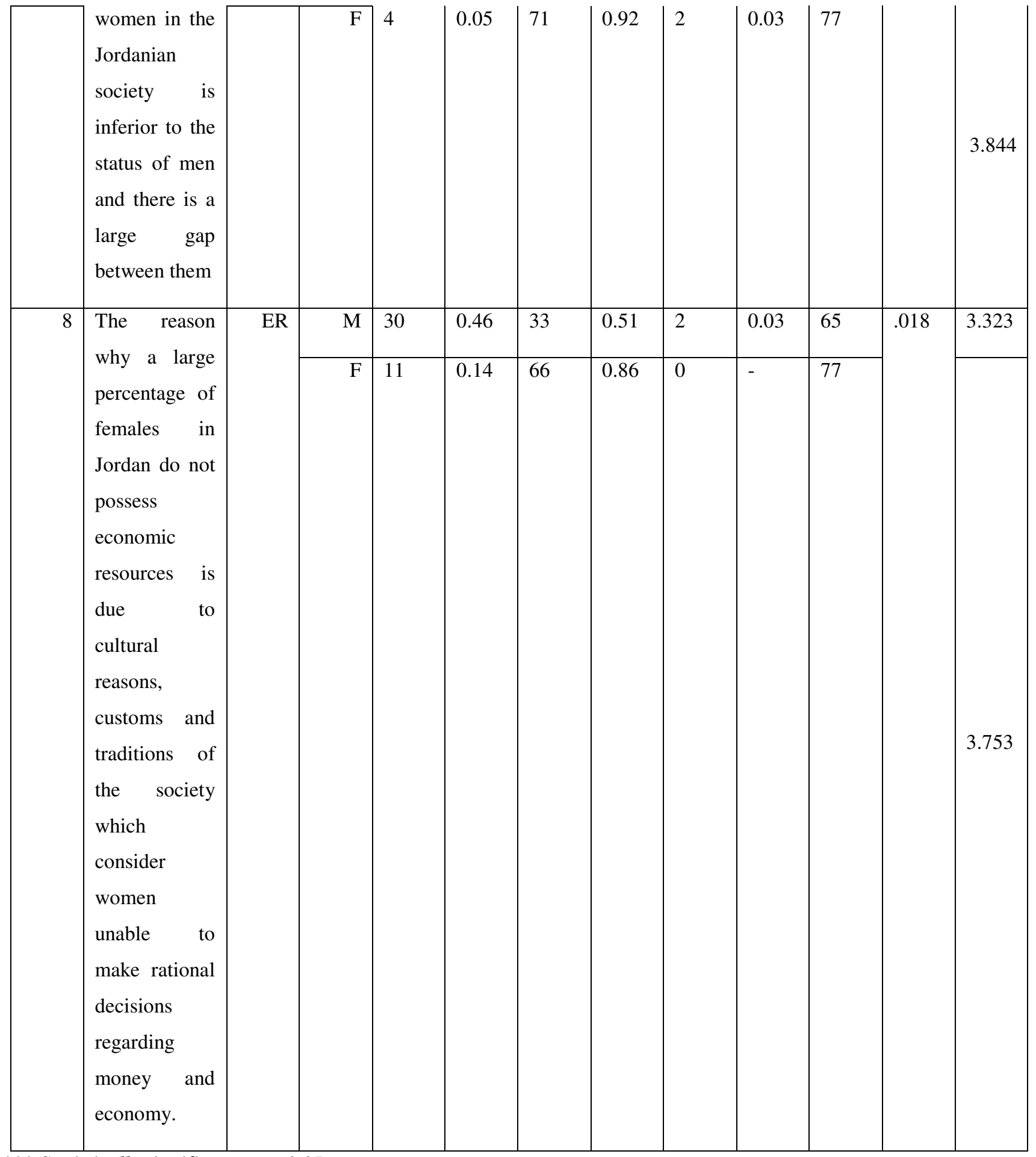

$* * *$ Statistically significant at $\alpha \leq 0.05$

The responses were more agreeing and means that ranged between 4,799 and 3,596 for males and females respectively. The highest means were for the statements: 'By providing government care centers and institutions with distinct levels and affordable prices for all, the society can bridge the gap in the position of women and men', 'One of the biggest causes that affect the status of women and men in the society is the distribution of time, effort and unpaid work', and 'The status of women in the Jordanian society is inferior to the status of men and there is a large gap between them'. Female attitudes and responses were very positive, and means of $(4.779,4.402,3.935)$. The males' responses were more 
neutral with means of $(3.307,3.076,2.461)$.

The females responses were higher for 'The law of inheritance and its regulations is the customary method in the Jordanian society that explains male ownership of property, real estate, and land', 'The reason why a large percentage of females in Jordan do not possess economic resources is due to cultural reasons, customs and traditions of the society which consider women unable to make rational decisions regarding money and economy', 'In the Jordanian society, parents prefer to register property, real estate, and land in the name of male children, not females, to preserve the family's property without transferring it to the daughter-in-law's family', 'Alimony law and regulations are the reason why females in the society do not possess economic resources', 'The reason why a large percentage of females in Jordan do not possess economic resources is because they are not involved in the labor market, and thus, they do not get paid work', and 'The reason that a large proportion of females in Jordan do not possess economic resources is because they exclusively perform the unpaid homework'. Females' attitudes were very positive towards these statements, and the means were reached (3.909, $3.753,3.597,3.974,3.974$, and 3.961), respectively.

The males' attitudes were all neutral and the means of their responses for the same statements were $(2.907,3.323$, $3.107,3.507,2.446$ and 3.507) respectively with the exception of the statement that a woman must obtain the approval of her husband or male family members even if she has the economic resources in order to be able to dispose of her property (i.e. buying or selling) which was very positive with a mean of 4.061. The females' response was neutral towards this point with a means of 2.987. As for the statement that shows the political participation of women in society and which states that a woman cannot votea candidate without the approval of her husband or male family, the male responseswere neutral with a mean of 2.984, while the females were more agreeingas the mean was 3.727. This indicates that they feel that this is the case in their community.

\section{DISCUSSIONS}

This study aimed to identify the extent of significant differences in the attitudes of husbands and wives towards unpaid work and the possession and control of economic resources and its relationship to the social status of both men and women in the society. The results showed that the females' attitudes were more negative than the males with regard to the division of work, unpaid tasks and activities in the home, and use of daily time.On the other hand, the males' attitudes were very positive towards the same issues, and this confirms the society's view that women need to be committed to their home and that they are associated with all the internal home roles; i.e. taking care of the children and the husband, providing services and following up on the children's education, as women are more suited for these tasks. Furthermore, women are looked upon as subordinate to men in everything, and that they need men and rely on them in everything outside the home because menare the stronger and moresuited for that. This is what is drawn up, formulated and molded socially and culturally, and reproduced in every generation, where the performance of women is measured by the extent of their dedication to unpaid domestic work and how they sacrifice everything to benefit the family financially and psychologically. Women sacrifice their health, economic status, external relations and their representation in the society and social statusin order to provide comfort totheir husbands, children, husband's family and those around them. In addition, if women have paid work outside the home, they are still the only one responsible for everything related to the care, service and education inside the home, and they need the approval of male family members on their work hours outside the home, their relationships and their behavior, and it is better to stay in their homes as much as possible. This is reflected, according to the respondents' opinion, on the way they usetheir time daily, especially leisure time, which according to the results are very little if any at all. They 
believe that they need more than 24 hours a day to accomplish their tasks, and that they need remindersto do these tasks. They also feel that theirefforts and time go without appreciation from those around them. These results were consistent with the results of (Balawi, 2018), (Gallup, 2017), (Al-Mayyali, 2014), and (Thibaud, 2010).

This is reflected on the woman's life as she finds herself forced to prefer working at home and taking care of her children in order to be able to provide the necessary time and effort for them. Subsequently, she becomes dependent on others because she does not have her own source of income with which her daily life runs. This is also reflected on her inability to own her own property such as a house or real estate that she may benefit from in case she needs financial resources as a future asset. According to the female respondents' viewpoints, this is a result to the alimony and inheritance laws, which focus on the role of males, and reinforces the differences in the division of roles between the two sexes. Likewise, the customs and traditions prefer different types of property to remain in the name of the male family members in order for women to stay subordinate to them. Men do not want their inheritance to go to the family of their daughter's husband (because he is a stranger) and thus mencan preserve the family's inheritance. In addition, the culture of society sees women as incapable of taking financial decisions and that they are protected by men and male relatives, whether husband, father or brother. Even if she has money or other economic resources, she is unable to dispose of it without the males' consent because she cannot bear the financial or legal consequences that she may be exposed to during the buying and selling processes and the various financial transactions because of the fear of its consequences. These results were consistent with Thibaud (2010), Department General Statistics(2016), and Gallup (2017).

As for the social status of women, the results indicated that the women had negative attitudes as most of them see that the status of women is inferior in society and that they cannot participate in the labor market due to the great limitations and obstacles they face while taking care of children and husband and service burdens at home and upbringing. They still face great challenges in political participation and the exercise of their rights to run for office, vote, express opinion and have leading roles in the society.In addition, women are exposed to great discrimination at work in favor of males in terms of the nature of work, level of employment, tasks and responsibilities assigned to each of them, in the assumption of higher positions at work and participation in decision-making. The results, further, indicated that the females and somewhat males agreed that the availability of government centers and institutions that provide care services for family members with certain quality standards and affordable wages for all may help bridge the gap in the status of women compared to men. Moreover, to bring about change, many laws and the customs and traditions related to the division of roles between the sexes need to be reviewed. The males' attitude was more neutral but closer to negative in many points related to the issue of the status of women in Jordan. These results were similar to the Department General Statistics (2016), Al-Majali(2002), Al-Balawi (2018) and Gallup (2017).

\section{RECOMMENDATIONS}

In light of the results and discussion above, the study recommends:

- Due to the importance of conducting studies that help achieve justice in society and bridgethe gap between the sexes in terms of human rights, there should be some sort of coordination between the academic bodies, especially the departments of sociology and centers that are concerned with gender and development issues, to update the curricula for graduate studies in a way that sheds light on gender and development in a broader way and in an integrated manner with other branches. 
- Coordinating with the relevant authorities to conduct a comprehensive analysis regarding the use of time and its importance to achieve development, through which gaps are identified in the field of unpaid work and care and home services tasks. This may establish an entry to reach justice in the distribution of roles and division of work in the family and society that may lead to having social justice.

- Working jointly to update school curricula, at all educational levels to incorporate modern concepts of social justice and development related to gender and human rights.

\section{REFERENCES}

1. Al-Balawi, Ibrahim, Moussaoui, and Dinazade (2018). Attitudes of university students towards the social status of women in the Algerian society. Science Horizons Journal. 3 (4), pp: 297-307.

2. Al-Majali, Shatha (2002). The Social Status and Social Position of Jordanian Bedouin Women: Stability and Change. Unpublished MA thesis, University of Jordan.

3. Al-Mayali, Mohsen (2014). The Impact of Behavioral Values on Determining the Social Status of Iraqi Women: a Field Study. Thi Qar Journal 9 (1), pp. 85-101

4. Al-Mujaydal, (2002). "University Youth Attitudes Towards Women's Work - A Field Study at Damascus University". Damascus University Journal. Volume (18), Issue 2, pp: 11-53

5. Al-Najjar, Fayez Juma, Al-Najjar, Nabil, Al-Zoubi, and Majid (2010). Methods of Scientific Research: Applied Perspective, 2nd Edition, Al-Hamed Publishing and Distribution House, Amman, Jordan.

6. Al-Sweiti, Abdel Nasser (2016). University youth attitudes towards the status of women in the Palestinian society- Hebron University. The International Journal of Specialized Education. 5 (6) 1-20.

7. Al-Zubaidi, Salem, Al-Hammadi, Abdulaziz (2012). Attitudes toward women's work in the military field. Journal of the American Arab Academy for Science and Technology. Volume (3), Issue (7), pp: 103-116.

8. Azizi, Khadija (2005). Philosophical Foundations of Western Feminist Thought, 1st Edition, Bisan House for Publishing, Distribution and Information, Beirut, Lebanon.

9. Cluster, Pierre (1991). Non-state society. Translated by Dr. Mohamed Hussein Dakroub, University Foundation for Studies, Publishing and Distribution, Beirut, Lebanon.

10. Department of General Statistics (2016). Gender issues: An analytical study. Based on the 2015 Census. Amman-Jourdan.

11. Department of General Statistics (2016). Main Findings Report of the Population and Housing Census, 2015.

12. Godens, Anthony (2005). Sociology: Translated by Fayez Al-Sabbagh, The Arab Organization for Translation, 4th Edition, Center for Arab Unity Studies, Beirut, Lebanon: pg. 763

13. International Labor Organization (2016). Report on Women at work. International Labor Office, Geneva.

14. International Labor Organization and Gallup, Inc. (2017). Towards Better Future for Women and Work: Voices of Women and Men. ISBN: 978-92-2-128961-6 (print), and ISBN: 978-92-2-128962-3.

15. Marx, Karl (1947). The Capital. Translated by Dr. Rashid Al-Beblawi, The Egyptian Renaissance Library House for Publishing, Cairo-Egypt. 
16. Sarri, Hilmi (2016). Social Media. First Edition, Dar Kunooz Al Marifa for Publishing and Distribution, Amman, Jordan.

17. Thebaud, Sarah (2010). "Masculinity, Bargaining and Dependency: Men's Understanding of domestic work in the cultural contexts of paid employment."Gender and Society, Cornell University. Vol.24, No.3, June- pp330-354.

18. United Nations (2015). Transforming Our World: The 2030 Agenda for Sustainable Development. http//www.un.org/ga/search/view_doc.asp?symbol=A/RES/70/1 \&Lang=A

19. United Nations (2017). Sustainable Development Goals Report. Taken from https://unctad.org/meetings/en/SessionalDocuments/ares70d1_en.pdf

20. United Nations (2019). Report of the global survey on the role of women in development: Reasons for the importance of addressing women's poverty caused by low income and time constraints to achieve sustainable development. https://undocs.org/ar/A/74/111. 